\title{
Impacts of Tropospheric Ozone on Growth and Yield of Rice (Oryza sativa L.)
}

\author{
Tetsushi YONEKURA, Tomohide SHIMADA, Makoto MIWA, Amaury ARZATE \\ and Kazuo OGAWA \\ Center for Environmental Science in Saitama, Kamitanadare 914, Kisai, Saitama 347-0015, Japan
}

\begin{abstract}
Sixteen rice cultivars (Koshihikari, Nipponbare, Akitakomachi, Hitomebore, Toyonishiki, Kinuhikari, Asanohikari, Sainokagayaki, Sakihatamochi, IR8, Boro8, Dawn, Te-tep, M401, Lemont and WSS-2) were exposed to three levels of ozone $\left(\mathrm{O}_{3}\right):<8 \mathrm{nl} \mathrm{l}^{-1}$, ambient levels, and $\times 1.5$ ambient levels in growth chambers placed at the Center for Environmental Science in Saitama (Kisai, Saitama Pref.) for 100 days between 29 June and 6 October 2003. The average concentration of $\mathrm{O}_{3}$ in mid-day $(0900-1700 \mathrm{~h})$ and the accumulated exposure to $\mathrm{O}_{3}$ above a threshold of $40 \mathrm{nl} \mathrm{l}^{-1}$ (AOT40) in the mid-day during experimental period was $41.0 \mathrm{nl} \mathrm{l}^{-1}$ and $37.71 \mu \mathrm{l}$ $\mathrm{l}^{-1} \mathrm{~h}$, respectively. The rice growth and its yield were reduced by exposure to $\mathrm{O}_{3}$. However, the reduction rate of yield affected by $\mathrm{O}_{3}$ was different among cultivars. In addition, the reduction rates of yields in Japanese rice cultivars were smaller than those in other cultivars. According to the prediction maps of yield-loss of rice affected by $\mathrm{O}_{3}$ in the Kanto district, Japan by using the method of AOT 40 - yield of rice response relationship, yield-loss in Japanese rice cultivars were about $25-35 \%$ larger compared with ambient $\mathrm{O}_{3}$ concentration.
\end{abstract}

Key words: Growth, Ozone, Prediction maps, Rice (Oryza sativa L.), Yield

\section{Introduction}

Industrial emissions of NOx and volatile organic compounds have led to increasing tropospheric ozone $\left(\mathrm{O}_{3}\right)$ concentration (Penkett, 1988). The $\mathrm{O}_{3}$ is recognized as a widespread phytotoxic air pollutant (Chameides $e t$ al., 1994), and many experimental studies have shown that $\mathrm{O}_{3}$ causes reductions in photosynthetic activity and dry matter production of crop plants (eg. Fuhrer $e$ t al., 1997). In Japan, relatively high concentrations of $\mathrm{O}_{3}$ have been detected, especially in urban areas, such as the Kanto district, and may be closely related to reduction of growth and yield of crops (Kobayashi, 1988).

Rice (Oryza sativa L.) is one of the most primary agricultural crops in Japan. There are studies on effects of $\mathrm{O}_{3}$ on rice growth and yield (Asakawa et al., 1981, Kats et al., 1995). Although the extent of $\mathrm{O}_{3}$ damage is different among cultivars of plants (Izuta et al., 1999), information about the influence of $\mathrm{O}_{3}$ on rice cultivars yield is rather limited. In addition, $\mathrm{O}_{3}$ dose - crop growth or yield response relationship have been derived in Europe and America (Fuhrer, et al., 1997). The concept of using the AOT (accumulated exposure to $\mathrm{O}_{3}$ over a threshold) to define long-term $\mathrm{O}_{3}$ exposure has been demonstrated to be appropriate for several types of vegetation (Fuhrer, et al., 1997). However, there are few reports which evaluated the influence of $\mathrm{O}_{3}$ on Japanese crop cultivars using the AOT concept (Kobayashi, 1999).

The object of this research is to evaluate sixteen cultivars sensitivity to $\mathrm{O}_{3}$, and to make prediction maps of yield-loss of rice affected by $\mathrm{O}_{3}$ in the Kanto district, Japan by using the method of $\mathrm{O}_{3}$ dose (AOT) - yield response relationship.

\section{Materials and Methods}

\subsection{Plant materials and stress treatments}

Sixteen cultivars of rice (Oryza sativa L.) were exposed to three different concentrations of $\mathrm{O}_{3}$ in growth chambers in 2003. Japanese rice cultivars of 'Koshihikari', 'Nipponbare', 'Akitakomachi', 'Hitomebore', 'Toyonishiki', 'Kinuhikari', 'Asanohikari', 'Sainokagayaki' and 'Sakihatamochi', and other rice cultivars, originated from Southeast Asia and America, of 'IR8' (Philippine), 'Boro8' (Pakistan), 'Lemont' (America), 'M401' (America), 'Dawn' (America), 'Te-tep' (Vietnam) and 'WSS-2' (Vietnam) were used for this experiment. The Japanese rice cultivars in our experiment were collected as relatively major cultivars in the Kanto district. All the rice seeds were obtained from the Saitama Prefectural Agriculture and Forestry Research Center. Rice seeds were pre-germinated in 
water for $\mathbf{4}$ days, three seeds sown into each plastic pots (30 cm in depth $\times 25 \mathrm{~cm}$ in diameter) filled with sand and grown in a greenhouse. After 10 days, the seedlings were moved into chambers and were then grown for 100 days from 29 June to 6 October 2003. Fertilizer (N-P-K=8:8:8) was applied before sowing at $8.9 \mathrm{~g}$ per pot. The growth chambers $\left(3.2 \mathrm{~m}^{2}\right.$ of growth space and $2 \mathrm{~m}$ in height; OTC- type 180, Koito Co. Japan) were located at the Center for Environmental Science in Saitama $\left(36^{\circ} 04 \mathrm{~N}, 139^{\circ} 31^{\prime} \mathrm{E}\right.$; Kisai, Saitama, Japan). three levels of $\mathrm{O}_{3}$ treatments described above were designated as charcoal-filtered air (CF), non-filtered air (NF) and proportional addition of $\mathrm{O}_{3}$ to achieve 1.5 times ambient $\mathrm{O}_{3}$ levels (1.5NF).

The concentration of $\mathrm{O}_{3}$ at the plant canopy height in each treatment was continuously monitored at 6-minute intervals with an $\mathrm{UV}$ absorption $\mathrm{O}_{3}$ analyzer (Model 1100, Dylec Inc., Japan). The $\mathrm{O}_{3}$ was generated from ambient air with an electrical discharge $\mathrm{O}_{3}$ generator (MO-5A, Nippon Ozone Co., Japan), and was then injected into the $1.5 \mathrm{NF}$ treatment during daytime. Average $\mathrm{O}_{3}$ concentration and the accumulated exposure to $\mathrm{O}_{3}$ over a threshold of $40 \mathrm{nl} \mathrm{l}^{-1}$ (AOT40) for 8 hours (from 0900 to $1700 \mathrm{~h}$ local time) in CF, NF and $1.5 \mathrm{NF}$ treatments are shown in Table 1.

On 6 October 2003 (100 days after treatment), all rice cultivars were harvested. Leaves and panicles from harvested plants were separated. Panicles were threshed to obtain the grain number and grain weight per plant.

\subsection{Prediction maps}

The data of $\mathrm{O}_{3}$ concentration from 1990 to 2000year in the Kanto district (Tokyo Metropolitan, Saitama Prefecture, Kanagawa Pref., Chiba Pref., Gunma Pref., Tochigi Pref. and Ibaraki Pref.) was provided from the 'Hourly Ambient Air Quality Data File' of Atmospheric Environmental Regional Observation System in the National Institute for Environmental Studies. Data of photochemical oxidant $\left(\mathrm{O}_{x}\right)$ concentration was considered as data of $\mathrm{O}_{3}$ concentration, because its monitoring system recorded $O_{x}$ concentration only. The number of monitoring stations of $\mathrm{O}_{\mathrm{x}}$ concentration in Tokyo, Saitama, Kanagawa, Chiba, Gunma, Tochigi and Ibaraki were $43,59,40,67,17,20$, and 31 , respectively. In each monitoring station, the average AOT40 was calculated by using the data of hourly $\mathrm{O}_{3}$ concentrations for 8 hours (from 0900 to $1700 \mathrm{~h}$ local time) during the growth period for 100 days between 1990 and 2000year. The process of estimating for AOT40 in 2050year is described below. The increase rate of average hourly $\mathrm{O}_{3}$ concentrations for 8 hours (from 0900 to $1700 \mathrm{~h}$ local
Table 1. Average $\mathrm{O}_{3}$ concentration, and the accumulated exposure to $\mathrm{O}_{3}$ over a threshold of 0 and $40 \mathrm{nl} \mathrm{l}^{-1}$ (AOTO and AOT40) for 8 hours (between 0900 and $1700 \mathrm{~h}$ local time) in CF, NF and 1.5NF treatments during the experimental period of 100 days from 29 June to 6 October 2003.

\begin{tabular}{|c|c|c|c|}
\hline Treatment & $\begin{array}{l}\text { Ave. } \mathrm{O}_{3} \text { con. } \\
\left(\mathrm{nl} \mathrm{I}^{-1}\right)\end{array}$ & $\begin{array}{c}\text { AOTO } \\
\left(\mu 11^{-1} h\right)\end{array}$ & $\begin{array}{l}\text { AOT40 } \\
\left(\mu 1 I^{-1} h\right)\end{array}$ \\
\hline $\mathrm{CF}$ & 5.0 & 4.75 & 0 \\
\hline NF & 41.0 & 37.71 & 12.30 \\
\hline $1.5 \mathrm{NF}$ & 58.3 & 53.57 & 28.89 \\
\hline
\end{tabular}

time) during the growth period for 100 days per year was calculated by using linear regression based on the data of hourly $\mathrm{O}_{3}$ concentrations from 1980 to 2000year. And then, at each monitoring point, the average hourly $\mathrm{O}_{3}$ concentrations and AOT40 in 2050year was estimated. Analyzing and mapping of these data were done by ArcGIS $^{\mathrm{TM}} 8$ (Arc View 8 and Spatial Analyst, ESRI Japan., Japan). The tension type of spline methods for estimation and interpolation of the values of $\mathrm{O}_{3}$ concentration among monitoring points were used.

\subsection{Statistical analysis}

The statistical analyses were performed with an SPSS statistical package (SPSS 10.0.5J, SPSS Japan Inc., Japan). The means were calculated from the three replicate blocks, and each block consisted of four seedlings. The grain yield relative to yield at the $\mathrm{CF}$ treatment was tested for best liner fit against the $\mathrm{O}_{3}$ dose (AOT40).

\section{Results and Discussion}

\section{$3.1 \mathrm{O}_{3}$ concentration and temperature}

During the growth period of 100 days, the AOT40 in $\mathrm{CF}, \mathrm{NF}$ and $1.5 \mathrm{NF}$ treatments were $0 \mu \mathrm{l} \mathrm{l}^{-1} \mathrm{~h}, 12.30 \mu \mathrm{l} \mathrm{l}^{-1}$ and $28.89 \mu \mathrm{I} \mathrm{I}^{-1} \mathrm{~h}$, respectively (Table 1). In the NF treatment, the $\mathrm{O}_{3}$ concentration was a relatively an average level compared with recent five years (data not shown). On the other hand, average daily air temperatures were $22.3^{\circ} \mathrm{C}$ in July and $25.5^{\circ} \mathrm{C}$ in August, and $23.3^{\circ} \mathrm{C}$ in September in 2003year. Compared with the recent five years' average temperature, low temperatures were recorded $\left(-3.4^{\circ} \mathrm{C}\right.$ in July, $-1.6^{\circ} \mathrm{C}$ in August, and $-0.4^{\circ} \mathrm{C}$ in September).

\subsection{Growth and yield}

Figure 1 illustrates the leaf number (a), the grain number (b), and the grain yield (c) relative to rice cultivars yield at the CF treatment. Table 2 shows the linear regression between relative grain yield at the $\mathrm{CF}$ treatment and AOT40, because the use of $40 \mathrm{nl} \mathrm{I}^{-1} \mathrm{O}_{3}$ 

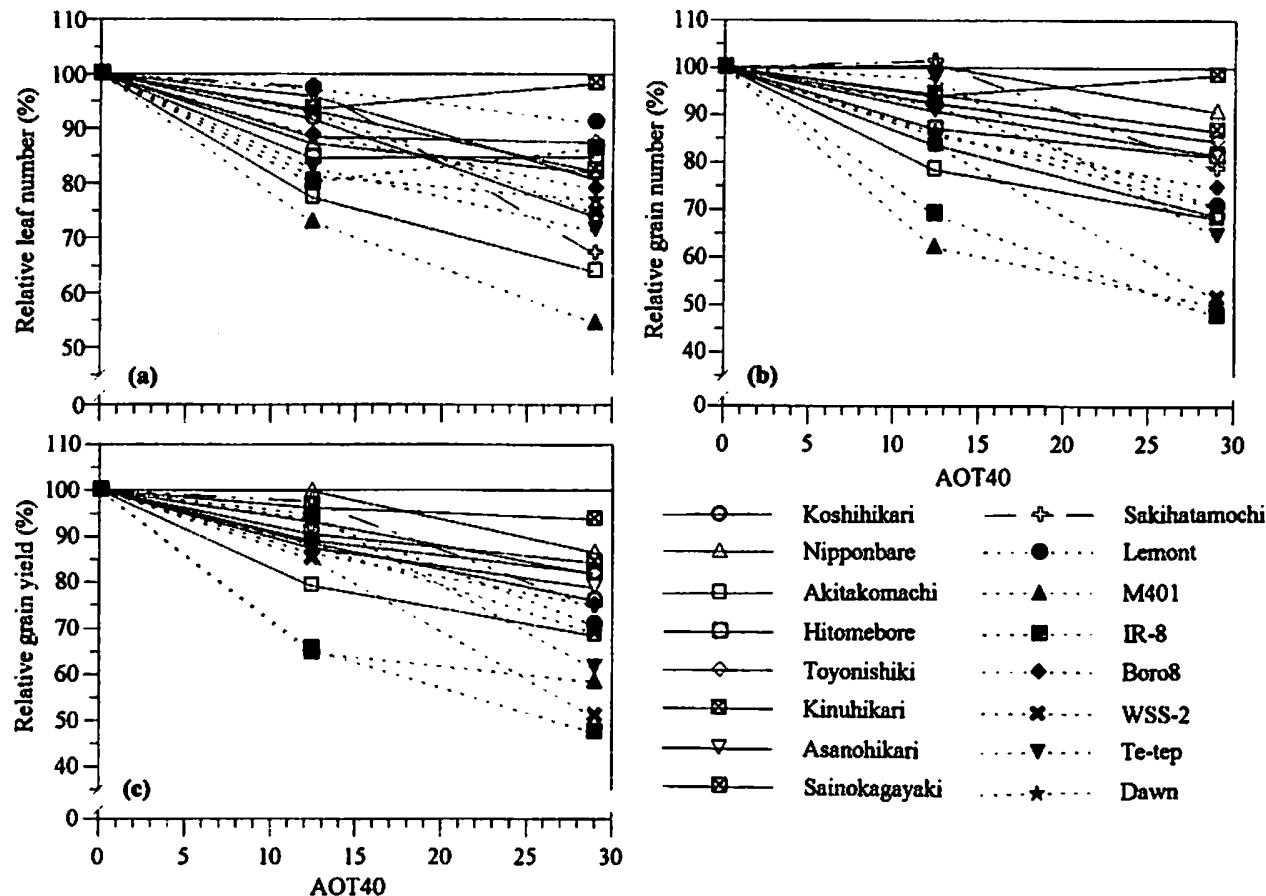

Fig. 1 Effects of $\mathrm{O}_{3}$ on the leaf number (a), grain number (b), and grain yield (c) relative to yield at the $\mathrm{CF}$ treatment of rice cultivars. The accumulated exposure to $\mathrm{O}_{3}$ over a threshold of $40 \mathrm{nl} \mathrm{I}^{-1}$ for 8 hours during the growth period of 100 days (AOT40) in CF, NF and $1.5 \mathrm{NF}$ treatments were $0,12.3$ and $28.9 \mu \mathrm{l} \mathrm{l}^{-1} \mathrm{~h}$, respectively (Table 1).

(giving the AOT40) as a threshold concentration gives a good linear fit to the growth or yield responses of plants (Fuhrer, et al., 1997). The reduction rates in all measurements were increased by the exposure to $\mathrm{O}_{3}$. However, growth responses (the number of leaves and panicles) affected by $\mathrm{O}_{3}$ were different from yield responses (the number of grains, and grain yield). Younglove et al. (1994) reported that response of plants to $\mathrm{O}_{3}$ changed during phenological growth stages. Especially, $\mathrm{O}_{3}$ exposures occurring before flowering and during pod filling may substantially affect yield (Kout and Laurence, 1983). We were unable to clarify the reason for the change in the responses by $\mathrm{O}_{3}$ fumigation, but similar works demonstrate that physiological responses were different among some crop cultivars (eg. Izuta et al., 1999). Furthermore, the reduction rates of yields in the Japanese rice cultivars were smaller than those in other cultivars originated from Southeast Asia and America. In Japanese rice cultivars, the sensitivity to $\mathrm{O}_{3}$ on yield was high in order of 'Akitakomachi', 'Sakihatamochi', 'Koshihikari', 'Asanohikari', 'Hitomebore', 'Sainokagayaki', 'Nipponbare' and 'Kinuhikari'. 'Koshihikari', the cultivar with the largest planted area (37\%) in Japan (Ministry of Agriculture, Forestry and Fisheries of Japan, 2004), had a relatively high $\mathrm{O}_{3}$ sensitivity on grain yield among Japanese rice cultivars. On the other hand, in other rice cultivars, the sensitivity to $\mathrm{O}_{3}$ on yield was high in order of ' $\mathbb{R} 8$ ',
'WSS-2', 'M401', 'Te-tep', 'Dawn', 'Lemont' and 'Boro8'.

Table 2. Linear regression between relative grain yield at CF treatment $\left(\% ; Y_{8}\right)$ and AOT $40\left(\mu 1 \mathrm{l}^{-1} \mathrm{~h}\right.$; $D)$. The data originated from Fig. 1. Japanese rice cv. means Kosihikari, Nipponbare, Akitakomachi, Hitomebore, Toyonishiki, Kinuhikari, Asanohikari, Sainokagayaki and Sakihatamochi. other rice cv. means Lemont, M401, R-8, WSS-2, Boro8, Te-tep and Dawn. $p$ value: ' $p<0.1, * p<0.05, * * *$ $p<0.001$.

\begin{tabular}{lll}
\hline \multicolumn{1}{c}{ Cultivar } & \multicolumn{1}{c}{ Regression line } & \multicolumn{1}{c}{ Coefficient $\left(R^{2}\right)$} \\
\hline All 16 cultivars & $Y_{8}=-0.95 D+99.7$ & $0.60^{* * *}$ \\
Japanese rice cv. & $Y_{8}=-0.67 D+99.3$ & $0.69^{* * *}$ \\
Other rice cv. & $Y_{8}=-1.31 D+99.6$ & $0.76^{* * *}$ \\
\hline Koshihikari & $Y_{8}=-0.82 D+99.5$ & $0.99^{*}$ \\
Nipponbare & $Y_{8}=-0.49 D+102.1$ & 0.83 \\
Akitakomachi & $Y_{8}=-1.06 D+97.2$ & 0.93 \\
Hitomebore & $Y_{8}=-0.61 D+99.0$ & 0.96 \\
Toyonishiki & $Y_{8}=-0.63 D+100.4$ & $0.99 *$ \\
Kinuhikari & $Y_{8}=-0.21 D+99.6$ & 0.96 \\
Asanohikari & $Y_{8}=-0.72 D+98.6$ & 0.96 \\
Sainokagayaki & $Y_{8}=-0.53 D+98.9$ & 0.96 \\
Sakihatamochi & $Y_{8}=-0.89 D+103.2$ & 0.88 \\
Lemont & $Y_{8}=-1.03 D+102.4$ & 0.94 \\
M401 & $Y_{8}=-1.37 D+93.3$ & 0.79 \\
IR-8 & $Y_{8}=-1.77 D+95.4$ & 0.93 \\
WSS-2 & $Y_{8}=-1.71 D+102.3$ & $0.98^{\dagger}$ \\
Boro8 & $Y_{8}=-0.85 D+98.9$ & $0.98^{\dagger}$ \\
Te-tep & $Y_{8}=-1.37 D+104.3$ & 0.90 \\
Dawn & $Y_{8}=-1.07 D+100.5$ & $0.99^{*}$ \\
\hline
\end{tabular}



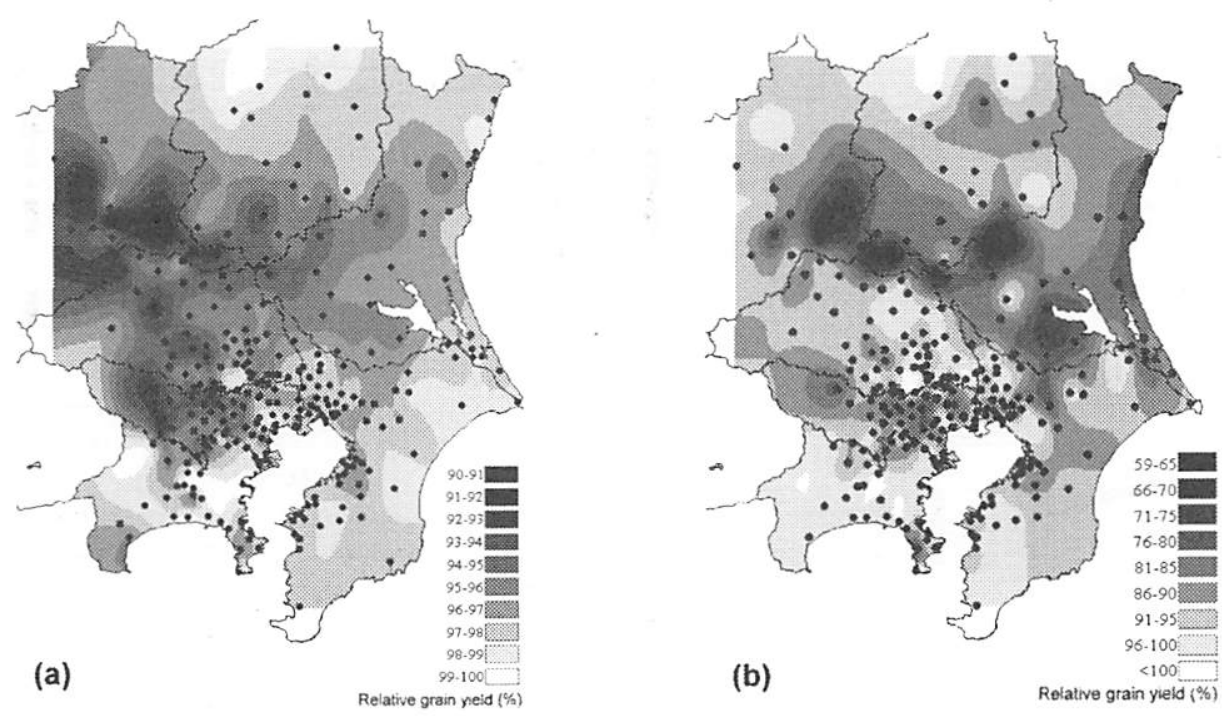

Fig. 2 Prediction map of yield-loss in Japanese rice cultivars in the Kanto district, Japan by using the method of AOT40 - rice yield response relationship (Table 2). (a) Ambient level of $\mathrm{O}_{3}$ (Average AOT40 during 1990 to 2000). (b) Increasing of $\mathrm{O}_{3}$ (AOT40 computed the prediction of $\mathrm{O}_{3}$ concentration in 2050).

\subsection{Prediction maps}

Figure 2. illustrates prediction maps of yield-loss affected by $\mathrm{O}_{3}$ in the Kanto district by using the method of $\mathrm{O}_{3}$ dose (AOT40) - yield of rice response relationship (Table 2). Japanese rice yield was reduced about $5-10 \%$ by ambient $\mathrm{O}_{3}$ concentration. In the areas of Tokyo, Saitama and Gunma, relatively higher reduction rate of rice yield was observed. On the other hand, according to the prediction of yield-loss in 2050year, the reduction rate of rice yield would be larger in almost all the Kanto area, and its would be about $25-35 \%$ large compared with the ambient levels of $\mathrm{O}_{3}$. Especially, rice yield in the areas of Gunma and Ibaraki would be reduced by exposure to $\mathrm{O}_{3}$. In the present study, the prediction of yield-loss of rice was based on the result of an average of nine Japanese cultivars, but 'Koshihikari' with the largest planted area $(64 \%)$ in the Kanto district had a larger yield reduction rate affected by $\mathrm{O}_{3}$. Thus, it is possible that the estimation of yield loss would be an underestimate. We predicted using only one experiment, but experiments over many years are required to raise the accuracy of the prediction.

\section{References}

Asakawa, F., Tanaka, H., and Kusaka, S., 1981: Effects of air filtration on rice growth and yield. Jpn. J. Soil sci. Plant Nutr. 52, 201-206 (in Japanese)

Chameides, W. L., Kasibhatla, P. S., Yienger, J., and Levy, H., 1994: Growth of continental-scale metro-agro-plexes, regional ozone pollution, and world food production. Science 64, 74-77

Fuhrer, J., Skärby, L., and Ashmore, M. R., 1997: Critical levels for ozone effects on vegetation in Europe. Environ. Pollut. 97, 91-106.

Izuta, T., Takahashi, K., Matsumura, H. and Totsuka, T. 1999: Cultivar difference of Brassica campestris L. in the sensitivity to $\mathrm{O}_{3}$ based on the dry weight growth. $J$. Jpn. Soc. Atmos. Environ, 34, 145-154.

Kats, G., Dawson, P. J., Bytnerowicz, A., Wolf, J. W., Thompson, C. R., and Olszyk, D. M. 1985: Effects of ozone or sulfur dioxide on growth and yield of rice. Agric. Ecosys. Environ. 14, 103-117.

Kobayashi, K., 1988: Effects of atomospheric ozone on the production of soybean and peanut in Kanto district of Japan. Environ. Pollut. 53, 437-438.

Kobayashi, K., 1999: Assessing the impacts of tropospheric ozone on agricultural production. J. Jpn. Soc. Atmos. Environ. 34, 162-175. (in Japanese)

Kout, R., and Laurence, J. A. 1983: Yield response of red kidney bean Phaseolus vulgaris to incentral ozone concentrations in the field. Environ. Pollut. 32, 233-240.

Ministry of Agriculture, Forestry and Fisheries of Japan, 2004: Statistics of Agriculture, Forestry and Fishers. (in Japanese)

Penkett, S. A., 1988: Indications and causes of ozone increase in the troposphere. In The Changing Atmosphere (sds. by Rowland, F. S., and Isaksen I. S. A.) John Wiley and Sons, London, pp. 91-103.

Younglove, T., McCool, P. M. Musselman, P. C. and Kahl, M. E. 1994: Growth-stage dependent crop yield response to ozone exposure. Environ. Pollut. 86, 287-295. 